\title{
Degradation of Acid Red 8 Dye Using Photo-Fenton Reaction Mediated by Titanium Modified Catalysts
}

\author{
André C. Bento, ${ }^{a}$ Elissandro S. Emídio, ${ }^{a, b}$ Peter Hammer ${ }^{a}$ and \\ Raquel F. P. Nogueira ${ }^{\circledR} *, a, b$ \\ ${ }^{a}$ Instituto de Química, Universidade Estadual Paulista (Unesp), 14800-060 Araraquara-SP, Brazil \\ ${ }^{b}$ Instituto Nacional de Tecnologias Alternativas para Detecção, Avaliação Toxicológica e \\ Remoção de Contaminantes Emergentes e Radioativos (INCT-DATREM), Instituto de Química, \\ Universidade Estadual Paulista (Unesp), CP 355, 14800-060 Araraquara-SP, Brazil
}

\begin{abstract}
Catalysts prepared by co-precipitation of iron and titanium were evaluated in heterogeneous photo-Fenton degradation of the azo dye Acid Red 8 under blacklight irradiation. Materials with different titanium contents $(0<\mathrm{Ti} / \mathrm{Fe}<0.6)$ were characterized using X-ray diffractometry, scanning electron microscopy, X-ray fluorescence spectroscopy, specific surface area and X-ray photoelectron spectroscopy. Hematite was identified as main phase in materials with lowest Ti content, while titanomaghemite was predominant at high Ti content. Highest degradation was obtained using titanium free catalyst due to iron leaching, which promoted a homogeneous reaction. Addition of $\mathrm{Ti}$ led to a heterogeneous process with a maximum when $\mathrm{Ti} / \mathrm{Fe}=0.40$ achieving $0.76 \mathrm{~mol}$ of dye mineralized per mol of soluble iron after $90 \mathrm{~min}$, using $10 \mathrm{mmol} \mathrm{L}^{-1} \mathrm{H}_{2} \mathrm{O}_{2}$ at $\mathrm{pH}$ 5.6, value at least three times higher than that observed for catalysts with lower Ti content. The results indicate that Ti stabilizes the catalyst and increases its heterogeneous activity in photo-Fenton process.
\end{abstract}

Keywords: azo dye, titanomaghemite, hematite, iron leaching, titanium

\section{Introduction}

Among the remediation processes for aquatic pollutants removal, the classical homogeneous Fenton system is a powerful source of oxidative $\mathrm{HO}^{*}\left(\mathrm{E}^{0}=2.80 \mathrm{~V} / \mathrm{SHE}\right)$ generated from decomposition of $\mathrm{H}_{2} \mathrm{O}_{2}$ in the presence of $\mathrm{Fe}^{2+}$ ions. ${ }^{1,2}$ It is one of the most effective advanced oxidation processes (AOP) and widely studied for efficient treatment of industrial wastewater containing nonbiodegradable organic pollutants. However, drawbacks such as the requirement of a low $\mathrm{pH}$ and a significant amount of ferric hydroxide sludge formed during the treatment have limited its application in homogeneous medium.,

Alternatively, heterogeneous Fenton systems based on solid iron phases and iron composite materials have been intensively studied to overcome the limitations of the homogeneous process. ${ }^{1,5}$ The most important features of iron oxides, commonly reported in literature, are the high surface-area, magnetism, biocompatibility, natural occurrence and catalytic oxidizing capabilities. ${ }^{6-9}$ Iron

*e-mail: raquel.pupo@unesp.br mineral oxides used to mediate heterogeneous Fenton reactions include goethite $(\alpha-\mathrm{FeOOH})$, maghemite $\left(\gamma-\mathrm{Fe}_{2} \mathrm{O}_{3}\right)$, hematite $\left(\alpha-\mathrm{Fe}_{2} \mathrm{O}_{3}\right)$ and magnetite $\left(\mathrm{Fe}_{3} \mathrm{O}_{4}\right)$. Among these, maghemite $\left(\gamma-\mathrm{Fe}_{2} \mathrm{O}_{3}\right)$ and magnetite $\left(\mathrm{Fe}_{3} \mathrm{O}_{4}\right)$ exhibit similar structure, high adsorption capacity and ferromagnetic behavior, facilitating the recovery of the catalyst. The use of these materials in the Fenton process involve $\mathrm{Fe}^{\mathrm{II}} / \mathrm{Fe}^{\mathrm{III}}$ redox cycles capable of catalytically decompose hydrogen peroxide and generate hydroxyl radical in a broad $\mathrm{pH}$ range. ${ }^{1,10-14}$

The incorporation of divalent ( $\mathrm{Co}, \mathrm{Ni}, \mathrm{Zn}$ and $\mathrm{Mn}$ ), trivalent ( $\mathrm{V}$ and $\mathrm{Cr}$ ) and tetravalent (Ti) ions in iron oxide structures are proposed to modify the surface properties and the oxidation efficiency for $\mathrm{H}_{2} \mathrm{O}_{2}$ decomposition in Fenton process. ${ }^{15-19}$

However, most of the heterogeneous Fenton catalysts developed so far are susceptible to iron leaching during the reaction, resulting consequently in the loss of catalytic activity combined to increasing iron sludge generation..$^{20,21}$

Synthetic organic dyes, widely used in food and textile industries, are frequently discharged inappropriately, with seriously harmful impact on the environment. Due to 
their high stability under sunlight, these contaminants can affect aquatic organisms by reducing the depth of light penetration. More recently, genotoxic and mutagenic effects of some classes of dyes have also been reported, alerting the seriousness of this type of pollutants..$^{22,23}$

In the effort to stabilize the ferrous structure and provide additional photocatalytic activity, the present study aims to verify the potential of titanium modified iron oxides in heterogeneous photo-Fenton process, synthesized using a simple co-precipitation method and characterized using different techniques. The Acid Red 8 (AR8) dye was investigated as a target contaminant under ultraviolet (UV) irradiation in the presence of $\mathrm{H}_{2} \mathrm{O}_{2}$. The influence of important process variables such as material composition, $\mathrm{H}_{2} \mathrm{O}_{2}$ concentration and initial $\mathrm{pH}$ are discussed in terms of dye degradation, solution discoloration, mineralization, hydrogen peroxide consumption, while stability of the materials was evaluated by soluble iron concentration and $\mathrm{X}$-ray photoelectron spectroscopy (XPS) analysis after degradation process.

\section{Experimental}

\section{Reagents}

Acid Red 8 dye $\left(\mathrm{C}_{18} \mathrm{H}_{14} \mathrm{~N}_{2} \mathrm{Na}_{2} \mathrm{O}_{7} \mathrm{~S}_{2} ; \mathrm{MM}=480.42 \mathrm{~g} \mathrm{~mol}^{-1}\right)$ (40\%) was obtained from Sigma-Aldrich (St. Louis, USA). $\mathrm{H}_{2} \mathrm{O}_{2} 30 \%(\mathrm{~m} / \mathrm{m})$ (Synth) was used. Bovine liver catalase was purchased from Sigma-Aldrich (St. Louis, USA). $0.06 \mathrm{~mol} \mathrm{~L}^{-1}$ ammonium metavanadate (Vetec, Rio de Janeiro, Brazil) was prepared in $0.36 \mathrm{~mol} \mathrm{~L}^{-1} \mathrm{H}_{2} \mathrm{SO}_{4}$ (Merck, Darmstadt, Germany) and used for hydrogen peroxide determination. Methanol (high-performance liquid chromatography (HPLC) grade, J.T.Baker, Xalostoc, Mexico) and ammonium acetate (Vetec, Rio de Janeiro, Brazil) 98\% were used in chromatographic analysis. Deionized water was used for dilutions and for HPLC analysis. A $0.2 \mathrm{~mol} \mathrm{~L}^{-1} \mathrm{H}_{2} \mathrm{SO}_{4}$ and $\mathrm{NaOH}$ (Chemis, São Paulo, Brazil) solutions were used for $\mathrm{pH}$ adjustment. Ammonium hydroxide $\left(27 \% \mathrm{NH}_{3}\right)$, $\mathrm{FeSO}_{4} \cdot 7 \mathrm{H}_{2} \mathrm{O}$ (Fmaia, São Paulo, Brazil), $\mathrm{Fe}_{2}\left(\mathrm{SO}_{4}\right)_{3} \cdot \mathrm{nH}_{2} \mathrm{O}$ (J.T.Baker, Phillipsburg, USA), titanium isopropoxide ( $\left.\mathrm{Ti}\left[\mathrm{OCH}\left(\mathrm{CH}_{3}\right)_{2}\right]_{4}, 97 \%\right)$ (Aldrich, St. Louis, USA) and isopropyl alcohol $\left(\mathrm{CH}_{3} \mathrm{CHOHCH}_{3}, 99.5 \%\right)$ (Synth, São Paulo, Brazil) were used for synthesis of the catalysts.

\section{Synthesis of catalysts}

The water content of ferric sulfate used in the synthesis was determined by thermogravimetric analysis and revealed 8 water molecules, stoichiometry used in calculations for the synthesis. A room temperature aqueous precipitation method was used to prepare titanium modified iron oxides in an anoxic atmosphere $\left(\mathrm{N}_{2}\right.$ flow $) .{ }^{24} \mathrm{~A}$ solution containing adequate quantities of $\mathrm{Fe}^{2+}$ and $\mathrm{Fe}^{3+}$ was prepared in $0.3 \mathrm{~mol} \mathrm{~L}^{-1} \mathrm{H}_{2} \mathrm{SO}_{4}$ and followed by addition of titanium isopropoxide solution in isopropyl alcohol (Table S1, Supplementary Information (SI) section). After $30 \mathrm{~min}$ a $0.3 \mathrm{~mol} \mathrm{~L}^{-1} \mathrm{NH}_{4} \mathrm{OH}$ solution was added dropwise under continuous stirring $(800 \mathrm{rpm})$, resulting in instantaneous precipitation of catalysts with molar ratios of Ti/Fe equal to 0.2, 0.4 and 0.6 named hereafter as CAT2, CAT3, CAT4, including the titanium free sample (CAT1).

The particles were separated from the aqueous phase by centrifugation and washed five times with deionized water under ultrasonication for $10 \mathrm{~min}$, followed by centrifugation at $4000 \mathrm{rpm}$ for $10 \mathrm{~min}$. After dried for $24 \mathrm{~h}$ at $80^{\circ} \mathrm{C}$ the solid was heated at $10{ }^{\circ} \mathrm{C} \mathrm{min}{ }^{-1}$ rate in a muffle furnace and sintered at $380^{\circ} \mathrm{C}$ for $10 \mathrm{~h}$ to obtain titanomaghemite.

\section{Characterization}

Nitrogen adsorption isotherms were recorded at liquid nitrogen temperature in a static volumetric apparatus supplied by Micromeritics ASAP 2010 (Atlanta, USA). Samples $(0.2 \mathrm{~g})$ were evacuated to about $10^{-6} \mathrm{~Pa}$ at $130^{\circ} \mathrm{C}$ for $24 \mathrm{~h}$ prior to measurements. The specific surface area, total pore volume and average pore size of synthesized materials were calculated following the Brunauer-EmmettTeller (BET) method. ${ }^{25}$

Scanning electron microscopy field emission gun (FEG-SEM) images were obtained with a JEOL microscope FEG-SEM JSM 6330F (Tokyo, Japan) operated at $5 \mathrm{kV}$. The samples for SEM were prepared by dropping an isopropyl alcohol suspension of the particles over a Si wafer, followed by drying under ambient conditions.

Semiquantitative multielemental analysis by non dispersive X-ray fluorescence (EDX) was carried out at room temperature in a Shimadzu Energy Dispersive X-ray Fluorescence Spectrometer, model EDX-720 (Kyoto, Japan). A Cu Ko radiation (of $15 \mathrm{kV}$ for $\mathrm{Na}, \mathrm{Mg}, \mathrm{P}, \mathrm{S}, \mathrm{Cl}$, $\mathrm{K}$ and $\mathrm{Ca}$ and $50 \mathrm{kV}$ for $\mathrm{Fe}, \mathrm{Ti}, \mathrm{Cu}$ and $\mathrm{Zn}$ ) with adjustable current up to $70 \mu \mathrm{A}$ was employed using a $10 \mathrm{~mm}$ collimator under vacuum with fixed counting time (100 s) for each analysis group.

$\mathrm{X}$-ray diffraction (XRD) measurements were performed at room temperature with a Siemens D5000 diffractometer (Munich, Germany), using $\mathrm{Cu} \mathrm{K} \alpha$ radiation $(\lambda=1.542 \AA$ ) selected by a curved graphite monochromator, over the $2 \theta$ range between $10^{\circ}$ and $90^{\circ}$ at a resolution of $0.01^{\circ}$.

X-ray photoelectron spectroscopy analysis (XPS) was carried out using a UNI-SPECS UHV Analysis System 
(Berlim, Germany) equipped with $\mathrm{Mg} \mathrm{K} \alpha(\mathrm{h}=1253.6 \mathrm{eV})$ as radiation source. The inelastic background of the highresolution core-level was subtracted using Shirley method. Charging effects were corrected using the $\mathrm{C} 1$ s hydrocarbon peak, fixed at a binding energy of $285.0 \mathrm{eV}$. The surface elemental composition was determined with a precision of $\pm 5 \%$ from the ratio of the relative peak intensities corrected by the Scofield atomic sensitivity factor. The spectra were deconvoluted using Voigt profiles formed by the combination of Gaussian and Lorentz curves using the CasaXPS software. ${ }^{26}$

\section{Degradation procedures}

Two $15 \mathrm{~W}$ black-light lamps with maximum emission at $365 \mathrm{~nm}$ were used for photodegradation experiments by irradiating inside a box a volume of $100 \mathrm{~mL}$ of AR8 solution with a depth of $3 \mathrm{~cm}$ (Figure S1, SI section). The $\mathrm{pH}$ of the AR8 solution $\left(25 \mathrm{mg} \mathrm{L}^{-1}\right)$ was adjusted to the desired $\mathrm{pH}$ value in the range of 2.6-7.2 by addition of $\mathrm{H}_{2} \mathrm{SO}_{4}$ or $\mathrm{NaOH}$ solution. After $\mathrm{pH}$ adjustment, the catalyst was dispersed in the solution in a $1 \mathrm{~g} \mathrm{~L}^{-1}$ dose and appropriate volume of $\mathrm{H}_{2} \mathrm{O}_{2}$ was added to the suspension while magnetically stirred to result in 3,5 or $10 \mathrm{mmol} \mathrm{L}^{-1}$ concentration besides in the absence of $\mathrm{H}_{2} \mathrm{O}_{2}$. Experiments were carried out at least in duplicate. For the experiments carried out in triplicate, standard deviations were calculated and are indicated in the Figures as error bars.

The possibility of catalyst reuse was evaluated after 30 min reaction cycles performed using the following conditions: AR8 concentration $=25 \mathrm{mg} \mathrm{L}^{-1}, 1.0 \mathrm{~g} \mathrm{~L}^{-1}$ CAT3, $\mathrm{pH}=5.6, \mathrm{H}_{2} \mathrm{O}_{2}$ concentration $=10 \mathrm{mmol} \mathrm{L}^{-1}$, under UV irradiation. After each run, catalyst that remained in the reaction was separated by vacuum filtration (acetate cellulose filter, $0.45 \mu \mathrm{m}$ ), washed with deionized water, and dried under vacuum at room temperature. The catalyst was then suspended in a fresh AR8 solution and used for the next catalytic cycle after restoring initial experimental conditions.

\section{Chemical analysis}

The concentration of AR8 during the experiments was determined using reversed-phase high performance liquid chromatography (HPLC) coupled to a diode array detector (DAD) (SPD-M20A). A C-8 column (Hyperclone C8-BDS $5 \mu \mathrm{m} \times 250 \times 4.6 \mathrm{~mm}$ from Phenomenex) was used and the mobile phase was a mixture of methanol:ammonium acetate $0.02 \mathrm{~mol} \mathrm{~L}^{-1}(28: 72, \mathrm{v} / \mathrm{v})$ at a flow rate of $1.0 \mathrm{~mL} \mathrm{\textrm {min } ^ { - 1 }}$ with detection at $508 \mathrm{~nm}$. The injection volume was $40 \mu \mathrm{L}$. Under these conditions, retention time of AR8 was $12.4 \mathrm{~min}$. The enzyme catalase was used to interrupt the
Fenton reaction by decomposing the residual $\mathrm{H}_{2} \mathrm{O}_{2}$ after adjustment of the $\mathrm{pH}$ to 6-7. The samples were then filtered through $0.45 \mu \mathrm{m}$ polyvinylidene difluoride membrane before HPLC analysis, which showed no retention of the dye. The results of AR8 concentration decrease during degradation measured using HPLC are referred in the text as AR8 degradation.

The AR8 absorbance at $508 \mathrm{~nm}$ was measured using a UVmini-1240 spectrophotometer (Shimadzu, Kyoto, Japan) immediately after sample withdrawal and filtration. The results are expressed in terms of relative absorbance $\left(\mathrm{Abs} / \mathrm{Abs}_{0}\right.$ ), where $\mathrm{Abs}_{0}$ corresponds to the initial absorption of the dye at $508 \mathrm{~nm}$ and Abs the absorption at time $t$, referred in the text as discoloration.

The residual hydrogen peroxide concentration was determined by measuring the absorption at $450 \mathrm{~nm}$ after filtration and reaction with ammonium metavanadate..$^{27}$ Briefly, $3.0 \mathrm{~mL}$ of filtered sample were immediately added to $1.0 \mathrm{~mL}$ ammonium vanadate solution $\left(6.2 \mathrm{mmol} \mathrm{L}^{-1}\right.$ in $0.058 \mathrm{~mol} \mathrm{~L}^{-1} \mathrm{H}_{2} \mathrm{SO}_{4}$ ) in a $10 \mathrm{~mL}$ volumetric flask. Absorption at $450 \mathrm{~nm}$ was measured after the volume adjustment and homogenization. Soluble total iron concentration was measured using 1,10-phenanthroline spectrophotometric method with maximum absorption at $510 \mathrm{~nm}$ after sample filtration..$^{28}$ Concentrations of both hydrogen peroxide and soluble total iron were determined only at the end of experiments, after $90 \mathrm{~min}$, when dye absorption at $508 \mathrm{~nm}$ was very low and caused no interference on determinations. UVmini-1240 spectrophotometer (Shimadzu, Kyoto, Japan) was also used to determine the residual $\mathrm{H}_{2} \mathrm{O}_{2}$ and soluble total iron concentrations.

The mineralization of organic matter during AR8 degradation was determined by measuring the decay of dissolved organic carbon concentration (DOC) using a total organic carbon analyzer (Shimadzu TOC 5000A, Kyoto, Japan) immediately after sample withdrawal and filtration. The DOC content includes the carbon from the target compound and from the degradation products generated during irradiation.

\section{Results and Discussion}

\section{Characterization}

The structure and phase composition of the materials with different $\mathrm{Ti}$ contents were assessed by recording $\mathrm{X}$-ray diffraction patterns (Figure 1). The positions and relative intensities of the XRD peaks correspond in good agreement with the JCPDS (Joint Committee on Powder Diffraction Standards) database to $\alpha$-hematite $\left(\alpha-\mathrm{Fe}_{2} \mathrm{O}_{3}\right.$, 
JCPDS 73-606) for the titanium free catalyst (CAT1). With the increase of Ti content to $\mathrm{Ti} / \mathrm{Fe}=0.22(\mathrm{CAT} 2)$ there is a change in the structure evidencing besides $\alpha$-hematite phase also the presence of titanium and iron oxide (JCPDS 89-2812). The predominance of the $\alpha-\mathrm{Fe}_{2} \mathrm{O}_{3}$ phase in catalysts CAT1 and CAT2 (Figures 1a and $1 \mathrm{~b}$ ) may be related to the oxidation of $\mathrm{Fe}^{\mathrm{II}}$ during the thermal treatment at $380{ }^{\circ} \mathrm{C} .{ }^{13}$

The catalysts with higher Ti content (CAT3 and CAT4) showed characteristic peaks of the titanomaghemite, $\mathrm{Fe}_{0.23}\left(\mathrm{Fe}_{1.95} \mathrm{Ti}_{0.42}\right) \mathrm{O}_{4}$ (JCPDS 84-1595), as main phase. Small peaks possibly related to hematite and titanate phases were also observed, however, their clear identification was hindered by the noise due to the strong fluorescence induced by the $\mathrm{Cu} \mathrm{K} \alpha$ radiation. ${ }^{29,30}$

The main diffraction peaks at $33^{\circ}$ and $36^{\circ}$, corresponding to rhombohedral cell of samples CAT1 and CAT2, and to cubic cell of CAT3 and CAT4 were used to estimate the crystallite size using Scherrer's equation (Table 1):

$\mathrm{d}=\frac{\mathrm{C} \lambda}{\left(\mathrm{B}_{\mathrm{M}}{ }^{2}-\mathrm{B}_{\mathrm{S}}{ }^{2}\right)^{1 / 2} \cos \theta}$

where $\mathrm{d}$ is the crystallite size, $\lambda$ is the wavelength of $\mathrm{X}$-rays, $\theta$ is the Bragg's angle, while $B_{M}$ and $B_{S}$ stand for the full width at half maximum (FWHMs) of the peak (in radians) corrected for instrumental broadening of the sample and the standard, respectively.

The lattice strain, $\eta$, was determined using the relation for peak broadening $B_{r} \cos \theta=\frac{k \lambda}{L}+\eta \sin \theta$, from the slope of the plot of $B_{r} \cos \theta v s$. $\sin \theta,{ }^{31}$ where $B_{r}$ is the width of the diffraction peak after subtracting the instrumental effect, $\mathrm{L}$ is the average crystallite size measured in a direction perpendicular to the surface of the specimen, and $\mathrm{k}$ is a constant $(\mathrm{k}=1.0)$. The variation of the lattice strain shows the increasing distortion of the structure due to the replacement of $\mathrm{Fe}^{\mathrm{III}}$ with $\mathrm{Ti}^{\mathrm{IV}}$, which leads to an ordering of $\mathrm{Fe}^{\mathrm{III}}$ and $\mathrm{Fe}^{\mathrm{II}}$ ions in octahedral sites. Negative values indicate that strain can be neglected considering the precision of the measurement of crystallite size. The replacement of $\mathrm{Fe}^{\mathrm{III}}$ tetragonal sites with $\mathrm{Ti}^{\mathrm{IV}}$ was evidenced by XPS analysis as will be discussed thereafter.

Changes in the structure, unit-cell dimensions, crystallite size and morphology have been ascribed to incorporation of ions into iron oxide, as in the case of $\mathrm{Ti}^{\mathrm{IV}}$ in the present work. ${ }^{32-34}$ The crystallite size has a strong influence on the surface area and consequently plays an important role on surface reactions. ${ }^{35}$ Table 1 shows that the increase of titanium content favors the formation of

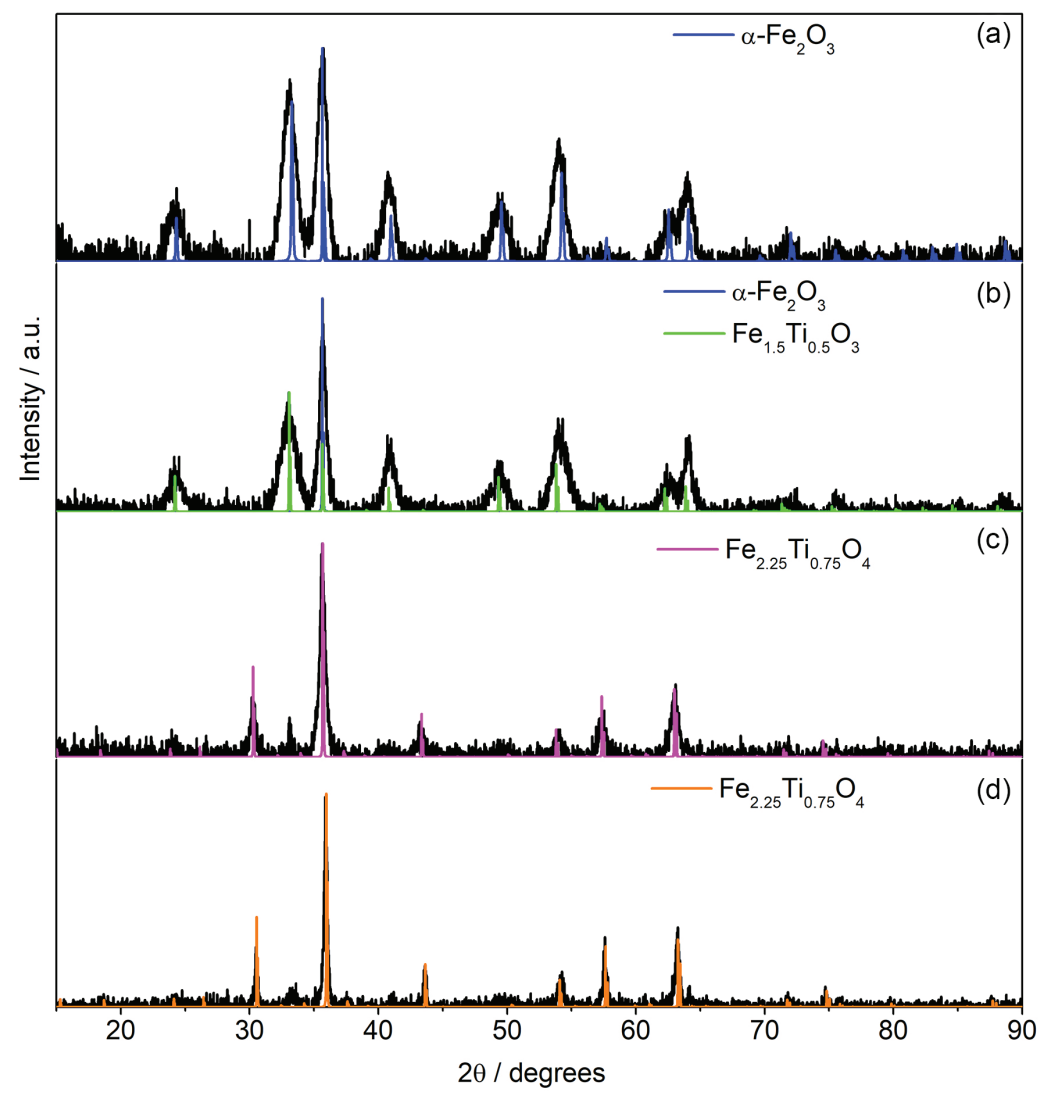

Figure 1. X-ray diffraction patterns of synthesized materials. (a) CAT1; (b) CAT2; (c) CAT3 and (d) CAT4. 
Table 1. Crystallite size and lattice strain of iron oxide phases containing different content of titanium

\begin{tabular}{lccc}
\hline & JCPDS & Crystallite size $(\mathrm{d}) / \mathrm{nm}$ & Lattice strain $(\eta)$ \\
\hline CAT1 & $\alpha$ - $\mathrm{Fe}_{2} \mathrm{O}_{3}(\alpha$-hematite) & $10.27 \pm 1.03$ & -0.09015 \\
CAT2 & $\alpha-\mathrm{Fe}_{2} \mathrm{O}_{3}(\alpha$-hematite $)$ & $21.48 \pm 2.15$ & 0.0791 \\
& $\mathrm{Fe}_{1.5} \mathrm{Ti}_{0.5} \mathrm{O}_{4}$ (titanium and iron oxide) & $4.29 \pm 0.43$ & -0.00411 \\
CAT3 & $\mathrm{Fe}_{0.23}\left(\mathrm{Fe}_{1.95} \mathrm{Ti}_{0.42}\right) \mathrm{O}_{4}$ (titanomaghemite) & $21.15 \pm 2.11$ & 0.00956 \\
CAT4 & $\mathrm{Fe}_{0.23}\left(\mathrm{Fe}_{1.95} \mathrm{Ti}_{0.42}\right) \mathrm{O}_{4}$ (titanomaghemite) & $34.57 \pm 3.46$ & 0.00723 \\
\hline
\end{tabular}

JCPDS: Joint Committee on Powder Diffraction Standards; CAT: catalyst.

larger crystallites, in agreement with values reported for $\alpha$-hematite and titanomaghemite. ${ }^{36,37}$

The scanning electron microscopy (FEG-SEM) images of CAT1 and CAT2 showed clusters of small particles with anisotropic morphology and size larger than $100 \mathrm{~nm}$ (Figures $2 \mathrm{a}$ and $2 \mathrm{~b}$ ). Similar morphologies containing aggregates with irregular shapes and micrometric size were previously observed for hematite phases. ${ }^{38}$ For samples with higher titanium content, the microstructure changes notably, showing for CAT3 agglomerates of spherical particle with diameters of less than $100 \mathrm{~nm}$ (Figure 2c), while CAT4 consists of a mixture of spherical and rod-like particles with similar size as those of CAT3 (Figure 2d).
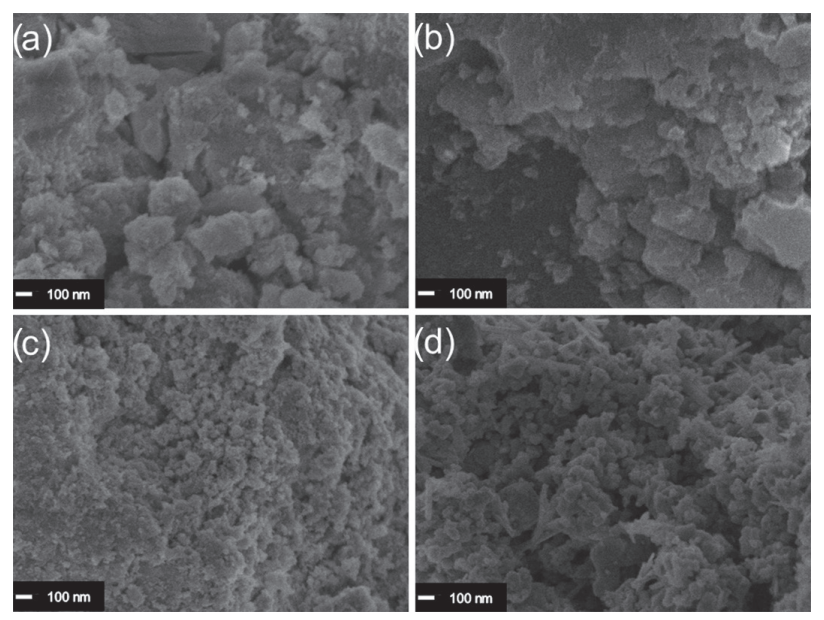

Figure 2. FEG-SEM images of titanium modified catalysts. (a) CAT1; (b) CAT2; (c) CAT3 and (d) CAT4.
Specific surface area results (BET), summarized in Table 2, showed that the morphological changes observed with increasing Ti content resulted in minor change of the specific surface area, except for CAT4, which increased about $50 \%$ compared to the titanium free sample. However, the average pore diameter decreased significantly from 17.6 to $5.1 \mathrm{~nm}$, resulting in a strong increase of the micropore area from 31.1 to $279.3 \mathrm{~m}^{2} \mathrm{~g}^{-1}$. These results suggest that titanium incorporation promotes a pronounced change in the porosity of the material, in agreement with textural parameters of iron(III) oxides containing Ti. ${ }^{39}$ It is interesting to note that despite the larger crystallite size of CAT2, its surface area is similar to CAT1, a consequence of its smaller average pore diameter than CAT1, which leads to a much higher micropore area than CAT1, compensating its larger crystallite size.

Hematite, $\alpha-\mathrm{Fe}_{2} \mathrm{O}_{3}$, is isostructural with $\mathrm{Al}_{2} \mathrm{O}_{3}$ and crystallizes as the corundum structure. The unit cell is hexagonal and contains 6 structural units of $\mathrm{Fe}_{2} \mathrm{O}_{3}$, with $\mathrm{Fe}^{\mathrm{III}}$ in two thirds of the octahedral interstices. ${ }^{40}$ Maghemite, $\gamma-\mathrm{Fe}_{2} \mathrm{O}_{3}$, is formed by oxidation of $\mathrm{Fe}_{3} \mathrm{O}_{4}$ and contains only $\mathrm{Fe}^{\mathrm{III}}$ states within the spinel structure. $\mathrm{Fe}$ vacancies are therefore required to ensure charge neutrality, according to the formula $\left(\mathrm{Fe}_{8}^{3+}\right)_{\text {tet }}\left[\mathrm{Fe}_{40 / 3}{ }^{3+} \mathrm{V}_{\mathrm{Fe} 8 / 3}\right]_{\text {oct }} \mathrm{O}_{32}$ (V: vacancy), with $\mathrm{Fe}$ vacancies present only in the octahedral sublattice. ${ }^{40}$ When doped with $\mathrm{Ti}^{\mathrm{IV}}$, an analogous binary titanomagnetite-titanomaghemite may be formed. Under adequate conditions, titanomagnetites are oxidized to form titanomaghemites where vacancy lattice sites are normally octahedric and the spinel titanomagnetite structure is maintained after oxidation. ${ }^{41,42}$

Table 2. Specific surface area, pore diameter, micropore area and volume of the titanium modified iron oxides prepared

\begin{tabular}{lccccc}
\hline & Ti/Fe & $\begin{array}{c}\text { Specific surface } \\
\text { area } /\left(\mathrm{m}^{2} \mathrm{~g}^{-1}\right)\end{array}$ & $\begin{array}{c}\text { Average pore } \\
\text { diameter } / \mathrm{nm}\end{array}$ & $\begin{array}{c}\text { Micropore } \\
\text { area } /\left(\mathrm{m}^{2} \mathrm{~g}^{-1}\right)\end{array}$ & $\begin{array}{c}\text { Micropore } \\
\text { volume } /\left(\mathrm{cm}^{3} \mathrm{~g}^{-1}\right)\end{array}$ \\
\hline CAT1 & 0 & $251 \pm 5$ & 17.6 & 31.1 & 0.04 \\
CAT2 & 0.22 & $265 \pm 1$ & 7.1 & 119.5 & 0.07 \\
CAT3 & 0.40 & $246 \pm 2$ & 6.9 & 160.7 & 0.09 \\
CAT4 & 0.61 & $379 \pm 1$ & 5.1 & 279.3 & 0.19 \\
\hline
\end{tabular}

CAT: catalyst. 
The formation of titanomaghemite occurs in the temperature range between 350 and $400{ }^{\circ} \mathrm{C}$. Therefore, for the used sintering temperature $\left(380{ }^{\circ} \mathrm{C}\right)$ a structural inversion is expected to occur. However, it is also known that the magnetite oxidation results in a structural deformation and nucleation of hematite on the crystallite surface, which was identified in CAT1 and CAT2 in XRD analysis. . $^{43,44}$

Consequently, the introduction of Ti in maghemite can change the physical properties of the material affecting the distribution of $\mathrm{Fe}^{\mathrm{II}}$ in tetrahedric and octahedric sites and the cationic distribution of the spinel structure can vary according to their forms, such as monocrystals, nanocrystalline powders or thin films. ${ }^{45,46}$

XPS high-resolution Fe 2p core-level peaks confirmed the presence of $\mathrm{Fe}^{\mathrm{III}}$ species. ${ }^{47,48}$ Figure 3 shows the deconvoluted $\mathrm{Fe} 2 \mathrm{p}_{3 / 2}$ and Ti $2 \mathrm{p}$ spectra of two chosen catalysts (CAT1 and CAT4) before and after the degradation assay. The low contribution of octahedral $\mathrm{Fe}^{\mathrm{II}}\left(<7 \%\right.$ peak intensity) and the predominance of $\mathrm{Fe}^{\mathrm{III}}$ in the octahedral and tetrahedral environment is in agreement with hematite and titanomaghemite phases identified by XRD (Figure 3 and Table 3). In the case of magnetite,
$\mathrm{Fe}_{3} \mathrm{O}_{4}$, three $\mathrm{Fe}$ environments with equal abundance (sub-peak intensity) would be expected ( $\mathrm{Fe}^{\mathrm{II}}$ octahedral, $\mathrm{Fe}^{\mathrm{III}}$ tetrahedral, $\mathrm{Fe}^{\mathrm{III}}$ octahedral), with increasing chemical shift, while for maghemite $\left(\gamma-\mathrm{Fe}_{2} \mathrm{O}_{3}\right)$ there are two ( $\mathrm{Fe}^{\mathrm{III}}$ octahedral, $\mathrm{Fe}^{\mathrm{III}}$ tetrahedral). ${ }^{47,49,50}$ Due to the moisture and exposure to aqueous environment during the degradation assays, also $\mathrm{Fe}^{\mathrm{III}}$ hydroxides $(\mathrm{FeOOH})$ are present $(732.5 \mathrm{eV})$, forming as the outermost surface layer. For the symmetrical $\mathrm{Ti} 2 \mathrm{p}$ spectra, only the $\mathrm{Ti}^{\mathrm{IV}}$ oxidation state was identified. The systematic decrease of the relative intensity of the tetrahedral $\mathrm{Fe}^{\mathrm{III}}$ component, observed in Table 3, indicates that $\mathrm{Ti}$ substituted $\mathrm{Fe}$ tetragonal sites and was possibly also introduced in the vacancies in octahedrical sites of the iron oxide structure. Furthermore, the comparison of spectra recorded before and after degradation experiments showed that they remained essentially unchanged, evidencing the stability of the catalysts (Figure 3).

Elemental composition of the catalyst, assessed by EDX, showed a good agreement with the nominal values considering the uncertainties of the analysis (Table 4). Results of the quantitative XPS analysis revealed, however, that the $\mathrm{Ti} / \mathrm{Fe}$ ratios of the near surface region are up to
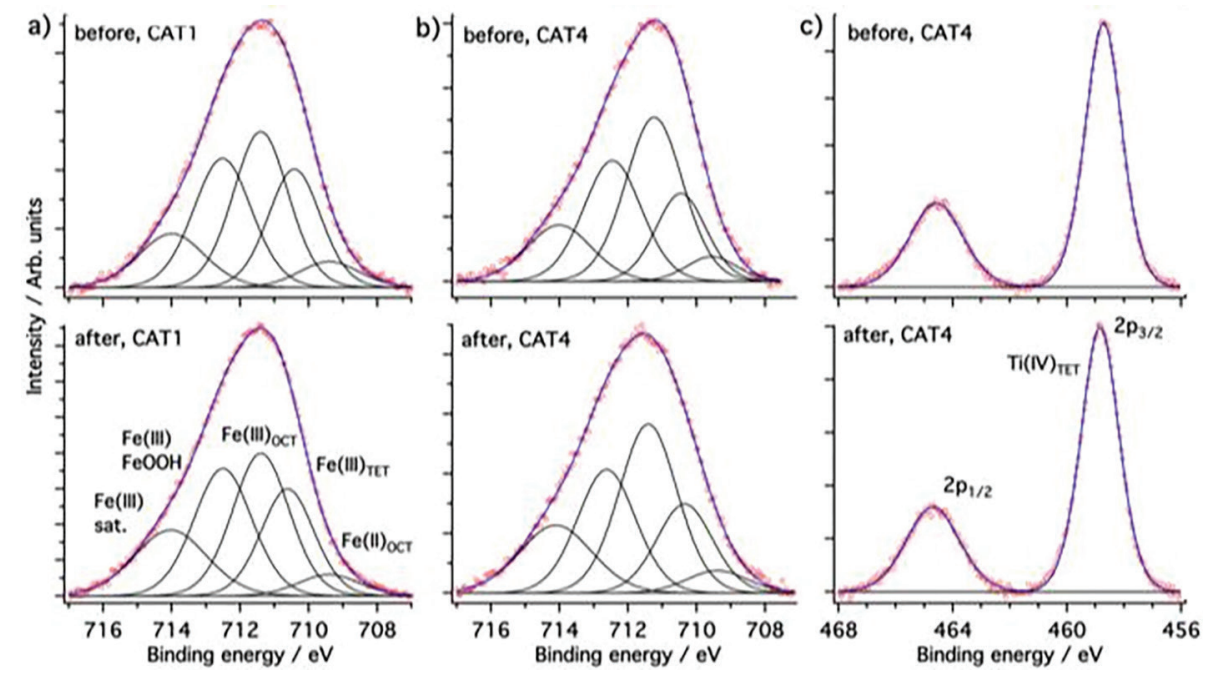

Figure 3. Deconvoluted XPS spectra recorded before and after degradation experiments: (a) Fe $2 p_{3 / 2}$ of CAT1; (b) Fe $2 p_{3 / 2}$ of CAT4; and (c) Ti 2 p of CAT4.

Table 3. Relative intensity and binding energies of different species identified in the Fe $2 \mathrm{p}_{3 / 2}$ and Ti $2 \mathrm{p}$ spectra

\begin{tabular}{|c|c|c|c|c|c|}
\hline \multirow[b]{2}{*}{ Sample } & \multicolumn{5}{|c|}{ Relative intensity of structural components / \% } \\
\hline & $\begin{array}{c}\mathrm{Fe}^{\mathrm{II}}{ }_{\mathrm{OCT}} \\
709.4 \mathrm{eV}\end{array}$ & $\begin{array}{c}\mathrm{Fe}^{\mathrm{III}}{ }_{\text {TET }} \\
710.4 \mathrm{eV}\end{array}$ & $\begin{array}{c}\mathrm{Fe}^{\mathrm{III}} \text { oCT } \\
711.3 \mathrm{eV}\end{array}$ & $\begin{array}{c}\mathrm{Fe}^{\mathrm{III}} \mathrm{FeOOH} \\
712.5 \mathrm{eV}\end{array}$ & $\begin{array}{c}\mathrm{Ti}^{\mathrm{iV}}{ }_{\text {TET }} \\
458.8 \mathrm{eV}\end{array}$ \\
\hline CAT 1 & 6.0 & 26.9 & 36.1 & 31.0 & 100 \\
\hline CAT 2 & 4.0 & 23.6 & 39.4 & 33.0 & 100 \\
\hline CAT 3 & 5.4 & 19.7 & 41.3 & 33.6 & 100 \\
\hline CAT 4 & 6.3 & 17.1 & 45.1 & 33.5 & 100 \\
\hline
\end{tabular}

CAT: catalyst; OCT: octahedral; TET: tetrahedral. 
Table 4. Comparison of the Ti/Fe ratio in the bulk (EDX) and surface (XPS) of the catalysts

\begin{tabular}{lccccc}
\hline Sample & Nominal & $(\mathrm{Ti} / \mathrm{Fe})_{\mathrm{EDX}^{\mathrm{a}}}$ & $(\mathrm{Ti} / \mathrm{Fe})_{\mathrm{XPS}}{ }^{\mathrm{a}}$ before & $(\mathrm{Ti} / \mathrm{Fe})_{\mathrm{XPS}} \mathrm{after}^{\mathrm{b}}$ & $(\mathrm{Ti} / \mathrm{Fe})_{\mathrm{XPS}} /(\mathrm{Ti} / \mathrm{Fe})_{\mathrm{EDX}}$ \\
\hline CAT2 & 0.22 & 0.24 & 0.7 & 0.8 & 2.96 \\
CAT3 & 0.40 & 0.37 & 1.0 & n.d. & 2.73 \\
CAT4 & 0.61 & 0.63 & 1.5 & 1.7 & 2.48 \\
\hline
\end{tabular}

${ }^{a}$ Experimental error (EDX, XPS): $\pm 10 \%$; ${ }^{b}$ after degradation assays. n.d.: not determined; EDX: dispersive X-ray fluorescence; XPS: X-ray photoelectron spectroscopy; CAT: catalyst.

three times higher than those obtained by EDX. Since the sampling depth of XPS is less than $5 \mathrm{~nm}$ and that of EDX up to $100 \mu \mathrm{m}$, reflecting the composition of the bulk, these results indicate that the iron deficiency on the surface might be caused by a leaching process, evidenced by the $\mathrm{Ti} / \mathrm{Fe}$ ratio increase observed for samples analyzed after the degradation process (Table 4). However, the observed decrease of $(\mathrm{Ti} / \mathrm{Fe})_{\mathrm{XPS}}$ to $(\mathrm{Ti} / \mathrm{Fe})_{\mathrm{EDX}}$ ratio with increasing $\mathrm{Ti}$ content indicates a tendency for stabilization of the titanomaghemite structure by $\mathrm{Ti}$, as will be discussed thereafter.

\section{Effect of titanium content on degradation of AR8}

In a first step, a set of control experiments was carried out to evaluate the contribution of direct photolysis of AR8 and $\mathrm{H}_{2} \mathrm{O}_{2}$ photolysis, dark reaction in the presence of CAT4 $(\mathrm{Ti} / \mathrm{Fe}=0.61)$ and $\mathrm{H}_{2} \mathrm{O}_{2}\left(10 \mathrm{mmol} \mathrm{L}^{-1}\right)$ (Figure $\left.4 \mathrm{a}\right)$ and adsorption of AR8 onto catalysts (dark and in absence of $\mathrm{H}_{2} \mathrm{O}_{2}$ ) (Figure $4 \mathrm{~b}$ ). The decrease of absorption of the chromophore group $(508 \mathrm{~nm})$ was used to evaluate the effect of different conditions. No direct photolysis of AR8 or degradation due to $\mathrm{H}_{2} \mathrm{O}_{2}$ photolysis was observed that could result in decrease of absorption of chromophore group (Figure 4a). No significant adsorption of AR8 onto catalysts CAT1, CAT2 and CAT3 was observed, while in the case of CAT4 adsorption achieved $20 \%$ already in the first 15 min during dark stirring (Figure 4b). Higher adsorption on catalyst with higher titanium content is a consequence of its around 50\% higher surface area in relation to the materials with lower titanium content, contributing to dye adsorption. However, after initial adsorption, the ratio Abs/Abs $s_{0}$ starts to increase probably due to a slight increase of dye solubility in solution or decrease of dye adsorption on catalyst during the experiment.

When AR8 was stirred in the presence of CAT4 and $\mathrm{H}_{2} \mathrm{O}_{2}$ in dark, a $25 \%$ decrease of absorption was observed after 90 min, which could indicate a dark heterogeneous Fenton reaction as already reported for different contaminants and iron materials. ${ }^{3,18,51}$ However, considering that the adsorption on this material was around $20 \%$, the dark Fenton contribution is not significant.

The influence of titanium content on catalytic activity of catalysts under blacklight irradiation was evaluated by monitoring the AR8 concentration during reaction (using HPLC) and by evaluating solution discoloration, measured by the decrease of absorption of the solution $(508 \mathrm{~nm})$. Furthermore, its activity for hydrogen peroxide decomposition was also evaluated as well as the stability of the material during the reaction by measuring the total soluble iron concentration leached from the materials.

Discoloration and degradation of AR8 decreased slightly when titanium content was increased from 0 to a Ti/Fe of 0.40 (CAT3) denoting that the titanium content influenced negatively the degradation of AR8 decreasing from 99 to $57 \%$ in the first 5 min reaction, respectively (Figure 5a).
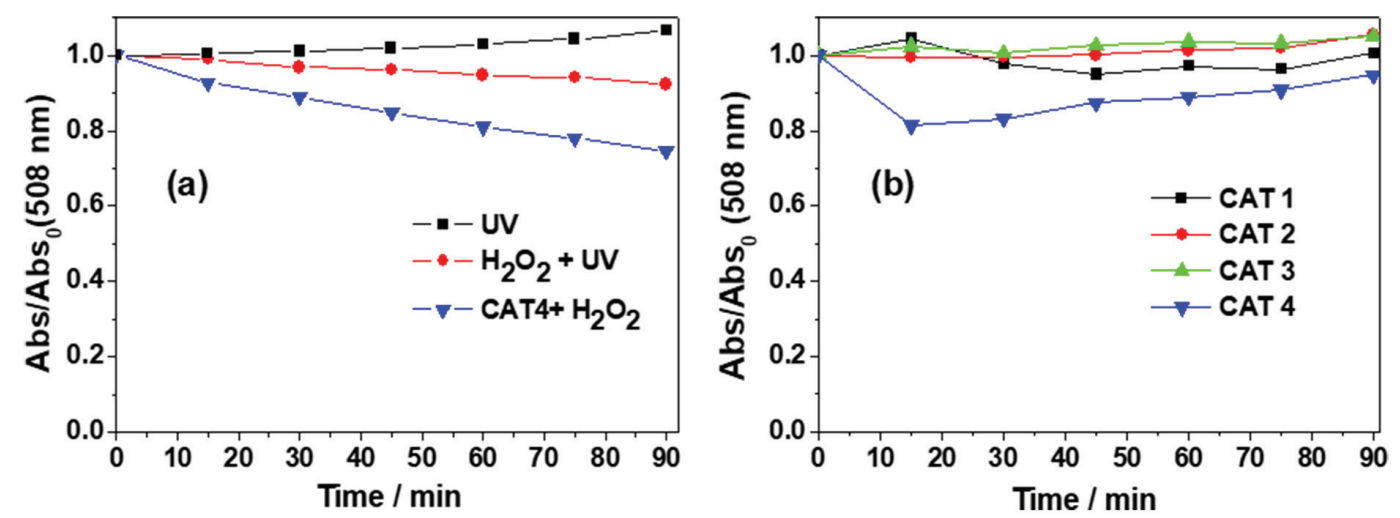

Figure 4. Effect of different experimental conditions on discoloration of AR8 (a) and effect of titanium content on AR8 adsorption on different catalysts in the dark (b). Initial conditions: $\mathrm{C}_{\mathrm{AR} 8}=25 \mathrm{mg} \mathrm{L}^{-1}, \mathrm{pH}=5.6$, catalysts dose $=1 \mathrm{~g} \mathrm{~L}^{-1}, \mathrm{H}_{2} \mathrm{O}_{2}=10 \mathrm{mmol} \mathrm{L}^{-1}$. 
However, even a stronger effect of titanium was observed with CAT4 $(\mathrm{Ti} / \mathrm{Fe}=0.61)$, achieving only $19 \%$ decrease of AR8 concentration after $45 \mathrm{~min}$, value similar to the adsorption obtained on this catalyst. A similar behavior was observed for absorption, where complete discoloration was observed after 10 min with CAT1, while CAT2 and CAT3 resulted in 89 and $52 \%$ after the same time, respectively (Figure 5b). For CAT4 a discoloration of $43 \%$ was observed after $90 \mathrm{~min}$. In the case of mineralization, evaluated by DOC removal, between 67 and 50\% were achieved for CAT1 and CAT3, respectively, and approximately $20 \%$ with CAT4 after 90 min (Figure 5c).

The negative effect of titanium content on the efficiency of the catalyst for the degradation of AR8 suggests that the process could be a result of a homogeneous reaction due to a possible instability of catalyst leading to an iron leaching process. The total iron concentration measured in solution after 90 min reaction revealed that the increase of Ti content resulted in a significant decrease of iron leaching with total iron concentration decreasing from 270 to $37 \mu \mathrm{mol} \mathrm{L}{ }^{-1}$ for CAT1 and CAT3, which corresponds to 2.5 and $0.6 \%$ of the total iron amount in the materials, respectively (Figure $5 \mathrm{~d}$ ). In the case of CAT4, the concentration of soluble iron could not be measured due to the high absorption of the solution since AR8 concentration was still high and interfered with the iron measurement. This iron concentration in the solution strongly affected $\mathrm{H}_{2} \mathrm{O}_{2}$ consumption, which was completely consumed for CAT1, while 58 and $54 \%$ of the initial $\mathrm{H}_{2} \mathrm{O}_{2}$ concentration were consumed in the case of CAT2 and CAT3, respectively (Figure 5c).

The obtained results indicate that the concentration of total dissolved iron significantly contributed to AR8 degradation by the homogeneous Fenton reaction. With the aim to determine the contribution of the heterogeneous process on the overall degradation for the different compositions, the molar fraction of AR8 mineralized after 90 min reaction per mole of total iron dissolved after 90 min was calculated and compared for the three catalysts. The relative mineralization increases with Ti content of the catalyst reaching a maximum of $0.76 \mathrm{~mol}$ of AR8 mineralized per mole of soluble iron for CAT3, revealing the heterogeneous contribution of this catalyst, while for materials with lower Ti content (CAT1 and CAT2), the homogeneous process prevails (AR8 degradation occurs mostly in solution) (Figure 5d). This result is supported by reduction of the $(\mathrm{Ti} / \mathrm{Fe})_{\mathrm{XPS}} /(\mathrm{Ti} / \mathrm{Fe})_{\mathrm{EDX}}$ ratio observed by XPS and EDX, indicating a decrease of iron surface leaching with increasing Ti content.

Both CAT3 and CAT4 were identified as titanomaghemite that has shown a good efficiency for phenol degradation in heterogeneous Fenton process. ${ }^{52}$ Significant iron leaching was also observed previously when using hematite and magnetite in heterogeneous photo-Fenton process, which
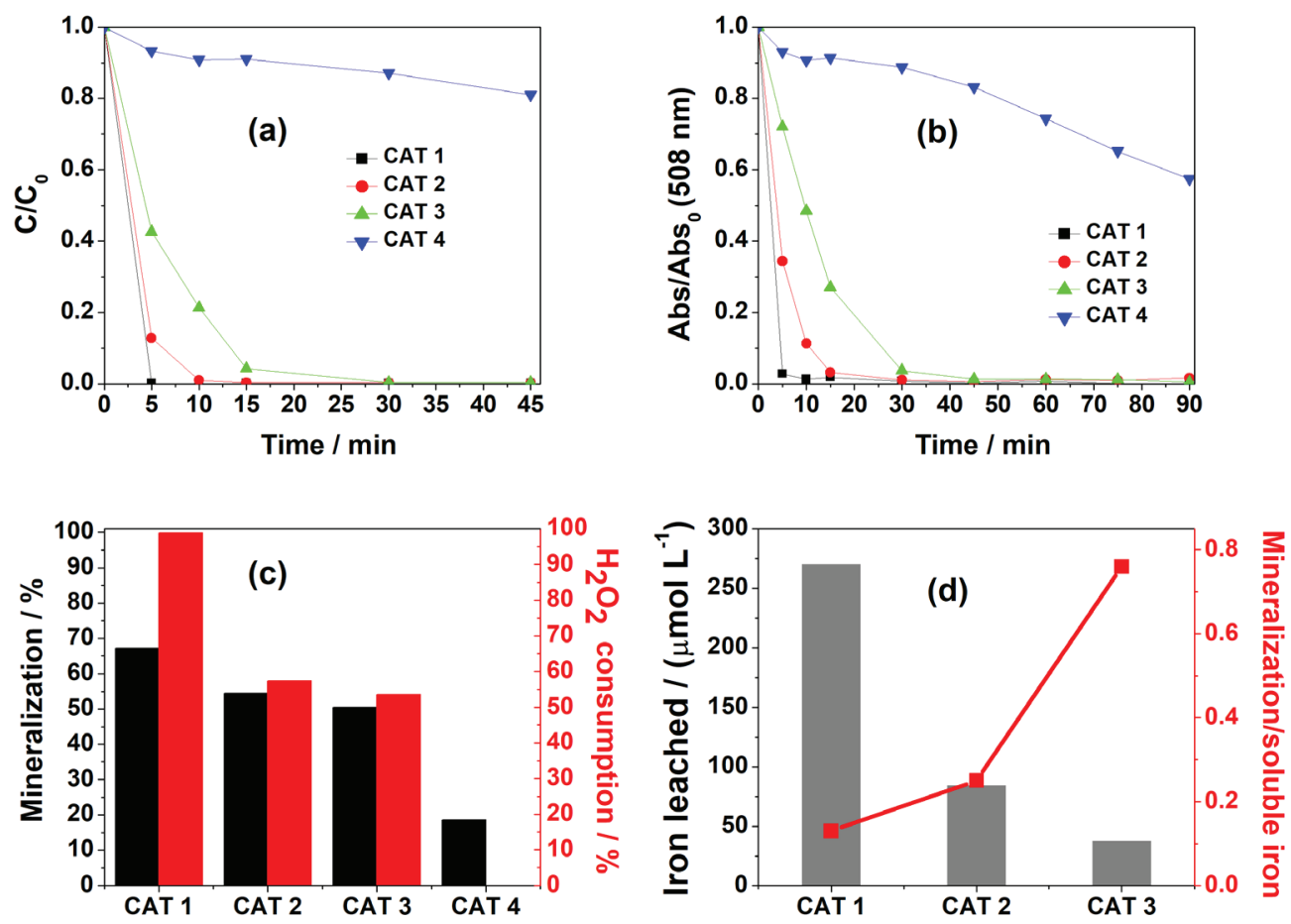

Figure 5. Effect of titanium content on AR8 degradation. (a) Degradation; (b) discoloration; (c) mineralization and $\mathrm{H}_{2} \mathrm{O}_{2}$ consumption after 90 min; (d) soluble iron concentration $\left(90 \mathrm{~min}\right.$ ) and $\mathrm{AR} 8 \mathrm{removed} / \mathrm{Fe}$ ratio $(5 \mathrm{~min})$. Initial conditions: $\mathrm{C}_{\mathrm{AR} 8}=25 \mathrm{mg} \mathrm{L}^{-1}, \mathrm{pH}=5.6, \mathrm{CAT}$ dose $=1.0 \mathrm{~g} \mathrm{~L}^{-1}, \mathrm{H}_{2} \mathrm{O}_{2}=10 \mathrm{mmol} \mathrm{L}^{-1}$, under UV irradiation. 
improved degradation. ${ }^{21,53}$ These results indicate that the iron leaching is influenced by the type of iron phases and that titanomaghemite has more favorable feature for heterogeneous Fenton process than hematite due to its higher activity and stability.

Considering the increased heterogeneous contribution of the catalyst CAT3 $(\mathrm{Ti} / \mathrm{Fe}=0.40)$ and its higher stability, the possibility of reuse of this catalyst was evaluated. Reuse of catalyst CAT3 resulted in a slight decrease of AR8 discoloration percentage from 91 to $83 \%$ after $30 \mathrm{~min}$ cycles, demonstrating no significant loss of activity for at least three cycles and the possibility of its reuse (Figure S3). Decrease of catalytic activity in heterogeneous process is often reported in the literature and is mainly related to agglomeration of the catalyst and occupation of reactive sites with degradation products. ${ }^{1,54}$

Catalyst CAT3 was used in further experiments to evaluate other degradation parameters such as $\mathrm{H}_{2} \mathrm{O}_{2}$ concentration and $\mathrm{pH}$.

\section{Effect of initial $\mathrm{H}_{2} \mathrm{O}_{2}$ concentration}

The influence of the initial concentration of hydrogen peroxide on AR8 degradation and discoloration was evaluated in the range from 3 to $10 \mathrm{mmol} \mathrm{L}^{-1}$ using $1 \mathrm{~g} \mathrm{~L}^{-1} \mathrm{CAT} 3$ and compared to that observed in the absence of $\mathrm{H}_{2} \mathrm{O}_{2}$. Figures $6 \mathrm{a}$ and $6 \mathrm{~b}$ show that the presence of $\mathrm{H}_{2} \mathrm{O}_{2}$ is essential to promote significant degradation, since very
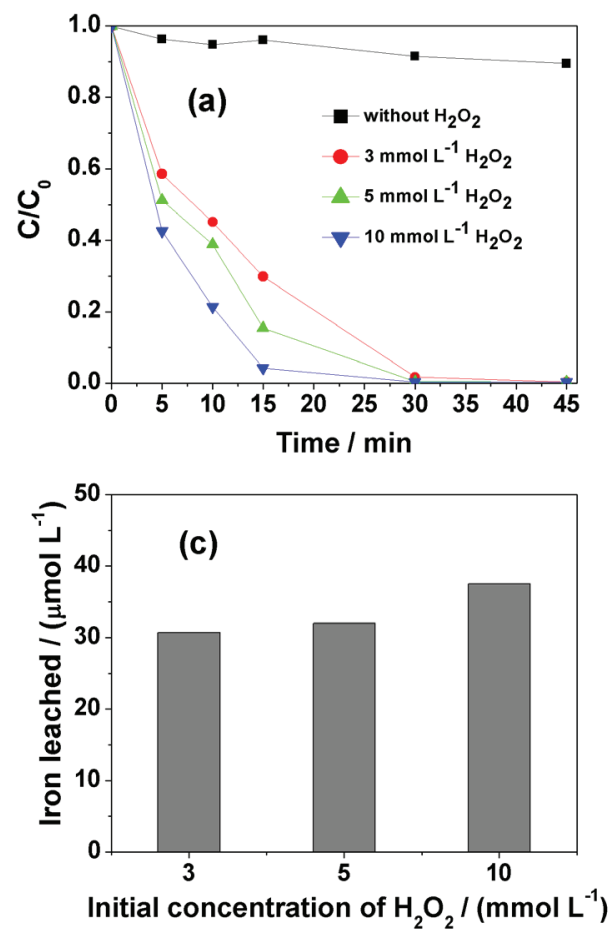

low AR8 degradation and discoloration was achieved in the absence of $\mathrm{H}_{2} \mathrm{O}_{2}$ indicating no significant photocatalytic activity of this material. However, the addition of $3 \mathrm{mmol} \mathrm{L}^{-1}$ of $\mathrm{H}_{2} \mathrm{O}_{2}$ led to a significant improvement of AR8 degradation which was further enhanced from 70 to $96 \%$ after 15 min reaction, when increasing $\mathrm{H}_{2} \mathrm{O}_{2}$ concentration from 3 to $10 \mathrm{mmol} \mathrm{L}^{-1}$.

The more pronounced effect of $\mathrm{H}_{2} \mathrm{O}_{2}$ on AR8 degradation and faster decrease of AR8 concentration than the absorbance indicates that hydroxyl radical attacks also other functional groups of the AR8 molecule besides the chromophore group, generating degradation products that still contain the azo group $(\mathrm{N}=\mathrm{N})$ in the structure as previously reported in the homogeneous photo-Fenton degradation of disperse red 1 dye. ${ }^{55}$ Absorption spectra of intermediates detected during AR8 degradation confirmed the presence of products with absorption bands around $500 \mathrm{~nm}$ as AR8 (maximum absorption at $508 \mathrm{~nm}$ ) corresponding to the presence of the azo group, which indicates an important degradation route through other functional groups besides of chromophore group (Figure S2, SI section).

Considering the stability of the material upon variation of $\mathrm{H}_{2} \mathrm{O}_{2}$ concentration, iron leaching did not play a significant role since the total iron concentrations in solution after $90 \mathrm{~min}$, varied only between 31 and $37 \mu \mathrm{mol} \mathrm{L}^{-1}$ (Figure 6c). This result also demonstrates the high stability of the material with Ti/Fe ratio of 0.4 .
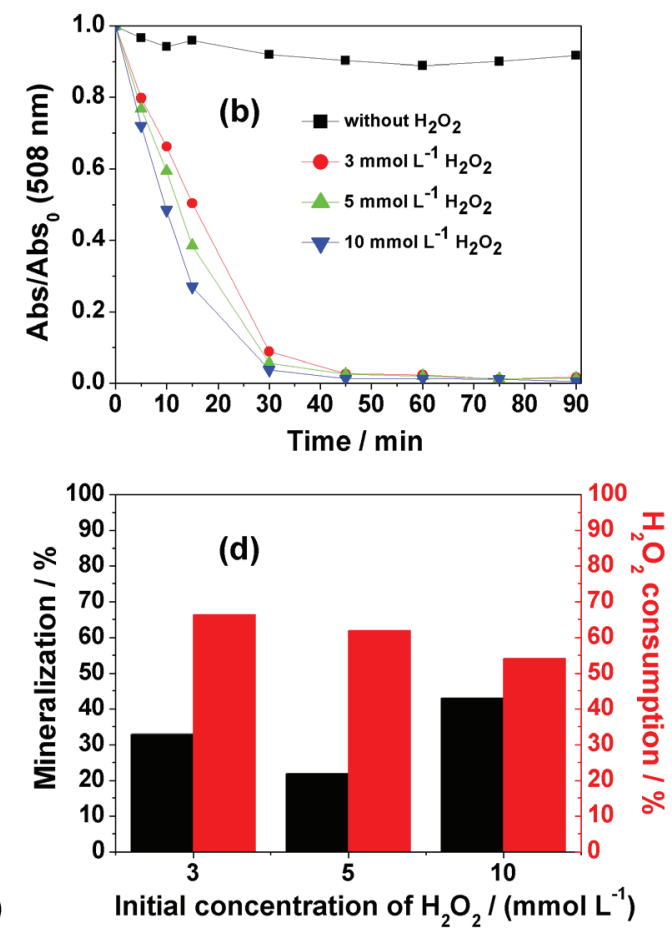

Figure 6. Effect of hydrogen peroxide initial concentration on AR8 degradation (a); discoloration (b); iron leaching (90 min) (c); mineralization of AR8 and consumption of $\mathrm{H}_{2} \mathrm{O}_{2}$ after 90 min reaction (d). Initial conditions: $\mathrm{C}_{\mathrm{AR} 8}=25 \mathrm{mg} \mathrm{L}^{-1}, \mathrm{pH}=5.6, \mathrm{CAT} 3$ dose $=1.0 \mathrm{~g} \mathrm{~L}^{-1}$, under $\mathrm{UV}_{\text {irradiation. }}$ 

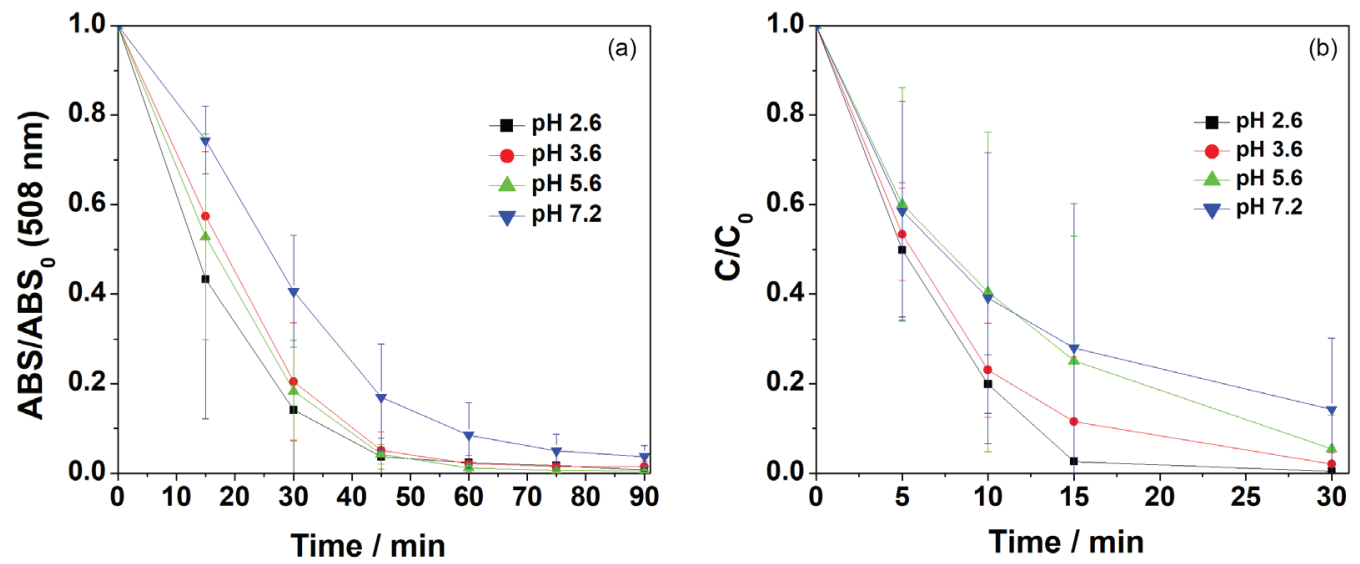

Figure 7. Effect of initial $\mathrm{pH}$ on AR8 discoloration (a) and degradation (b). Initial conditions: $\mathrm{C}_{\mathrm{AR} 8}=25 \mathrm{mg} \mathrm{L} \mathrm{L}^{-1}$, $\mathrm{CAT}_{3}$ dose $=1.0 \mathrm{~g} \mathrm{~L}^{-1}, \mathrm{H}_{2} \mathrm{O}_{2}=10 \mathrm{mmol} \mathrm{L}^{-1}$, under UV irradiation.

Consumption of $\mathrm{H}_{2} \mathrm{O}_{2}$ ranged from $66 \%$ when initial $\mathrm{H}_{2} \mathrm{O}_{2}$ concentration was $3 \mathrm{mmol} \mathrm{L}^{-1}$ and $54 \%$ in the case of $10 \mathrm{mmol} \mathrm{L}^{-1}$, corresponding to an absolute $\mathrm{H}_{2} \mathrm{O}_{2}$ consumption of 2 and $5.4 \mathrm{mmol} \mathrm{L}^{-1}$ (Figure 6d). This relatively high consumption of $\mathrm{H}_{2} \mathrm{O}_{2}$ indicates the availability of $\mathrm{Fe}$ in the material for reaction with $\mathrm{H}_{2} \mathrm{O}_{2}$. Furthermore, the highest mineralization of $43 \%$ was achieved using the initial $\mathrm{H}_{2} \mathrm{O}_{2}$ concentration of $10 \mathrm{mmol} \mathrm{L}^{-1}$.

Considering the significant improvement on AR8 degradation, discoloration and mineralization using $10 \mathrm{mmol} \mathrm{L}^{-1}$, this concentration was adopted in further experiments.

\section{Effect of initial pH}

The influence of initial $\mathrm{pH}$ on the discoloration of AR8 solution was investigated adjusting the initial $\mathrm{pH}$ to 2.6 , 3.6, 5.6 and 7.2 and using $10 \mathrm{mmol} \mathrm{L}^{-1} \mathrm{H}_{2} \mathrm{O}_{2}$ and $1 \mathrm{~g} \mathrm{~L}^{-1}$ CAT3 as initial concentrations. In homogeneous phase, acidic conditions are very important to promote Fenton degradation processes. In heterogeneous processes, Fenton reactions are also favored under acidic conditions, since in alkaline conditions, decomposition of $\mathrm{H}_{2} \mathrm{O}_{2}$ to $\mathrm{H}_{2} \mathrm{O}$ and $\mathrm{O}_{2}$ is favored decreasing its concentration for Fenton reaction, which highest effectiveness is in the $\mathrm{pH}$ range 3.0-6.0. ${ }^{56-58}$ Surprisingly, in the present study, the discoloration efficiency of AR8 decreased only slightly with increase of $\mathrm{pH}$ with no significant difference between $\mathrm{pH}$ 2.6-5.6 ( $t$ test, $\mathrm{P}=0.05$; Figure $7 \mathrm{a}$ ) achieving total discoloration after $60 \mathrm{~min}$. However, with further $\mathrm{pH}$ increase to 7.2, a slower degradation was evident.

When monitoring the $\mathrm{pH}$ dependence of AR8 concentration, the difference of profiles was more pronounced, showing a decrease of the degradation efficiency after $30 \mathrm{~min}$ from 95 to $86 \%$ when increasing the $\mathrm{pH}$ to 5.6 and 7.2, respectively (Figure 7b). For lower $\mathrm{pH}$ values ( $\mathrm{pH} 2.6$ and 3.6) the AR8 concentration was below detection limit after the same time. These results open the possibility to carry out degradation in less acid conditions or natural $\mathrm{pH}$ of dye solution ( $\mathrm{pH}$ 5.6), overcoming one of the main limitations of the Fenton process, which notably influence the Fenton reaction for contaminants degradation, especially in homogeneous medium. In heterogeneous medium, different results are reported in relation to the $\mathrm{pH}$ dependence. Discoloration of Orange II using $\mathrm{ZnFe}_{2} \mathrm{O}_{4}$ increased with increase of $\mathrm{pH}$ and with best results at $\mathrm{pH} 6,{ }^{59}$ while acidic medium $(\mathrm{pH} 2)$ favored the degradation of 4-chlorophenol in the $\mathrm{Fe}_{3} \mathrm{O}_{4} @ \beta-\mathrm{CD} / \mathrm{H}_{2} \mathrm{O}_{2}$ system. ${ }^{3}$ These results suggest that the choice of the type of catalyst allows the use of heterogeneous Fenton reaction over a wide range of $\mathrm{pH}$ values for catalytic degradation of contaminants.

\section{Conclusions}

Iron oxides with different contents of titanium $(0<\mathrm{Ti} / \mathrm{Fe}<0.6)$ were prepared, characterized and evaluated for AR8 dye degradation. The catalysts with lower titanium content (molar ration $\mathrm{Ti} / \mathrm{Fe}=0$ and 0.2 ) presented hematite as main phase, while titanomaghemite was detected as main phase in catalysts with higher titanium content $(\mathrm{Ti} / \mathrm{Fe}=0.4$ and 0.6). XPS analysis revealed a low abundance of the $\mathrm{Fe}^{\mathrm{II}}$ octahedral environment with predominance of $\mathrm{Fe}^{\mathrm{III}}$ in octahedral and tetrahedral sites, the latter preferentially substituted by Ti. The increase of titanium content improved the stability of the catalysts as lower iron leaching was observed when compared to titanium free catalyst, in which the soluble iron concentrations contributed significantly to homogeneous reaction. Highest heterogeneous contribution to the photo-Fenton process was observed with catalyst with molar ratio $\mathrm{Ti} / \mathrm{Fe}=0.4$, achieving a complete degradation of AR8 after $30 \mathrm{~min}$ at $\mathrm{pH}$ 5.6. The catalysts showed low dependence on initial $\mathrm{pH}$ value, which permits its 
application at near neutral conditions overcoming the main limitation of Fenton process.

\section{Supplementary Information}

Supplementary information (table showing the amounts of reagents used for preparation of catalysts; schematic view of irradiation system; UV-Vis spectra of degradation products; graphic showing the reuse of catalyst) is available free of charge at http://jbcs.sbq.org.br as PDF file.

\section{Acknowledgments}

The authors are grateful to FAPESP for financial support (research grant No. 2015/21732-5) and for a postdoctoral fellowship awarded to E. S. E. (grant No. 2016/11373-0). The authors thank also CAPES for scholarship awarded to A. C. B.

\section{References}

1. Mirzaei, A.; Chen, Z.; Haghighat, F.; Yerushalmi, L.; Chemosphere 2017, 174, 665.

2. Pignatello, J. J.; Oliveros, E.; MacKay, A.; Crit. Rev. Environ. Sci. Technol. 2006, 36, 1.

3. Wang, M.; Fang, G.; Liu, P.; Zhou, D.; Ma, C.; Zhang, D.; Zhan, J.; Appl. Catal., B 2016, 188, 113.

4. Zhang, Y.; Zhou, M.; J. Hazard. Mater. 2019, 362, 436.

5. Jain, B.; Singh, A. K.; Kim, H.; Lichtfouse, E.; Sharma, V. K.; Environ. Chem. Lett. 2018, 16, 947.

6. Oliveira, L. C. A.; Fabris, J. D.; Pereira, M. C.; Quim. Nova 2013, 36, 123.

7. Perez, J. M.; Nat. Nanotechnol. 2007, 2, 535.

8. Ranji-Burachaloo, H.; Gurr, P. A.; Dunstan, D. E.; Qiao, G. G.; ACS Nano 2018, 12, 11819.

9. Xu, P.; Zeng, G. M.; Huang, D. L.; Feng, C. L.; Hu, S.; Zhao, M. H.; Lai, C.; Wei, Z.; Huang, C.; Xie, G. X.; Liu, Z. F.; Sci. Total Environ. 2012, 424, 1.

10. Munoz, M.; De Pedro, Z. M.; Casas, J. A.; Rodriguez, J. J.; Appl. Catal., B 2015, 176, 249.

11. Nidheesh, P.; RSC Adv. 2015, 5, 40552.

12. Wang, N.; Zheng, T.; Zhang, G.; Wang, P.; J. Environ. Chem. Eng. 2016, 4, 762.

13. Yang, S.; He, H.; Wu, D.; Chen, D.; Liang, X.; Qin, Z.; Fan, M.; Zhu, J.; Yuan, P.; Appl. Catal., B 2009, 89, 527.

14. He, J.; Yang, X.; Men, B.; Wang, D.; J. Environ. Sci. 2016, $39,97$.

15. Liang, X.; Zhu, S.; Zhong, Y.; Zhu, J.; Yuan, P.; He, H.; Zhang, J.; Appl. Catal., B 2010, 97, 151.

16. Magalhães, F.; Pereira, M.; Botrel, S.; Fabris, J.; Macedo, W.; Mendonca, R.; Lago, R.; Oliveira, L.; Appl. Catal., A 2007, 332,115 .
17. Pires, M. S.; Nogueira, F. G. E.; Torres, J. A.; Lacerda, L. C. T.; Correa, S.; Pereira, M. C.; Ramalho, T. C.; RSC Adv. 2016, 6, 80830.

18. Pouran, S. R.; Raman, A. A. A.; Daud, W. M. A. W.; J. Cleaner Prod. 2014, 64, 24.

19. Zhong, Y.; Liang, X.; Tan, W.; Zhong, Y.; He, H.; Zhu, J.; Yuan, P.; Jiang, Z.; J. Mol. Catal. A: Chem. 2013, 372, 29.

20. Hartmann, M.; Kullmann, S.; Keller, H.; J. Mater. Chem. 2010, 20, 9002 .

21. Rodríguez, E. M.; Fernández, G.; Álvarez, P. M.; Hernández, R.; Beltrán, F. J.; Appl. Catal., B 2011, 102, 572.

22. Oliveira, D. P.; Carneiro, P. A.; Sakagami, M. K.; Zanoni, M. V. B.; Umbuzeiro, G. A.; Mutat. Res., Genet. Toxicol. Environ. Mutagen. 2007, 626, 135.

23. Vacchi, F. I.; Vendemiatti, J. A. S.; da Silva, B. F.; Zanoni, M. V. B.; Umbuzeiro, G. A.; Sci. Total Environ. 2017, 601, 230.

24. Guigue-Millot, N.; Champion, Y.; Hytch, M. J.; Bernard, F.; Begin-Colin, S.; Perriat, P.; J. Phys. Chem. B 2001, 105, 7125.

25. Gregg, S. J.; Sing, K. S. W.; Adsorption, Surface Area, and Porosity; Academic Press: London, 1991.

26. CasaXPS Processing Software, version 2.3.19; Casa Software Ltd., Teignmouth, UK, 2018.

27. Nogueira, R. F. P.; Oliveira, M. C.; Paterlini, W. C.; Talanta 2005, 66, 86.

28. Fortune, W. B.; Mellon, M. G.; Ind. Eng. Chem., Anal. Ed. 1938, 10,60 .

29. West, A. R.; Solid State Chemistry and Its Applications; John Wiley \& Sons Ltd.: Chichester, 1984.

30. Janssens, K. In Handbook of Spectroscopy; Wiley-VCH Verlag GmbH \& Co. KGaA: Weinheim, 2005, p. 363.

31. Suryanarayana, C.; Norton, M. G.; X-Ray Diffraction; Springer: Boston, MA, 1998.

32. Krehula, S.; Musić, S.; J. Cryst. Growth 2008, 310, 513.

33. Krehula, S.; Musić, S.; J. Alloys Compd. 2012, 516, 207.

34. Krehula, S.; Štefanić, G.; Zadro, K.; Krehula, L. K.; Marciuš, M.; Musić, S.; J. Alloys Compd. 2012, 545, 200.

35. Nogueira, A. E.; Castro, I. A.; Giroto, A. S.; Magriotis, Z. M.; J. Catal. 2014, 2014, 6.

36. O'Donovan, J. B.; O'Reilly, W. In Origin of Thermoremanent Magnetization; O’Donovan, J. B.; O’Reilly, W.; Dunlop, D. J., eds.; Springer: Dordrecht, 1977, ch. 1.

37. Özdemir, Ö.; Banerjee, S. K.; Geophys. Res. Lett. 1984, 11, 161.

38. Mechakra, H.; Sehili, T.; Kribeche, M. A.; Ayachi, A. A.; Rossignol, S.; George, C.; J. Photochem. Photobiol., A 2016, $317,140$.

39. Oulego, P.; Villa-Garcia, M. A.; Laca, A.; Diaz, M.; Dalton Trans. 2016, 45, 9446.

40. Parkinson, G. S.; Surf. Sci. Rep. 2016, 71, 272.

41. O'Reilly, W.; Phys. Earth Planet. Inter. 1983, 31, 65. 
42. Pearce, C. I.; Qafoku, O.; Liu, J.; Arenholz, E.; Heald, S. M.; Kukkadapu, R. K.; Gorski, C. A.; Henderson, C. M. B.; Rosso, K. M.; J. Colloid Interface Sci. 2012, 387, 24.

43. Readman, P. W.; O'reilly, W.; Phys. Earth Planet. Inter. 1971, $4,121$.

44. Cornell, R. M.; Schwertmann, U.; The Iron Oxides: Structure, Properties, Reactions, Occurrences and Uses, $2^{\text {nd }}$ ed.; John Wiley \& Sons: Weinheim, 2003.

45. Bowles, J. A.; Jackson, M. J.; Berquó, T. S.; Sølheid, P. A.; Gee, J. S.; Nat. Commun. 2013, 4, 1.

46. Kim, K. J.; Koh, T. Y.; Kim, C. S.; Lee, Y. B.; J. Korean Phys. Soc. 2014, 64, 93.

47. Grosvenor, A. P.; Kobe, B. A.; Biesinger, M. C.; McIntyre, N. S.; Surf. Interface Anal. 2004, 36, 1564.

48. Poulin, S.; França, R.; Moreau-Bélanger, L.; Sacher, E.; J. Phys. Chem. C 2010, 114, 10711.

49. Murphy, S.; Cazacu, A.; Berdunov, N.; Shvets, I. V.; Mukovskii, Y. M.; J. Magn. Magn. Mater. 2005, 290-291, 201.

50. Shannon, R. D.; Acta Crystallogr., Sect. A: Found. Adv. 1976, $32,751$.

51. Xu, X.; Pliego, G.; Garcia-Costa, A. L.; Zazo, J. A.; Liu, S.; Casas, J. A.; Rodriguez, J. J.; Appl. Catal., B 2018, 232, 429.
52. Jin, M.; Long, M.; Su, H.; Pan, T.; Zhang, Q.; Wang, J.; Zhou, B.; Zhang, Y.; Environ. Sci. Pollut. Res. 2017, 24, 1926.

53. Martínez, F.; Calleja, G.; Melero, J. A.; Molina, R.; Appl. Catal., B 2007, 70, 452.

54. Bai, Z.; Yang, Q.; Wang, J.; Environ. Prog. Sustainable Energy $\mathbf{2 0 1 7}, 36,1743$.

55. Leite, L. D. S.; Maselli, B. D. S.; Umbuzeiro, G. D. A.; Nogueira, R. F. P.; Chemosphere 2016, 148, 511.

56. Cheng, M.; Zeng, G.; Huang, D.; Liu, L.; Zhao, M.; Lai, C.; Huang, C.; Wei, Z.; Li, N.; Xu, P.; Zhang, C.; Li, F.; Leng, Y.; Biochem. Eng. J. 2014, 84, 9.

57. Moradi, S. E.; Dadfarnia, S.; Shabani, A. M. H.; Emami, S.; Turk. J. Chem. 2017, 41, 426.

58. Cheng, M.; Lai, C.; Liu, Y.; Zeng, G.; Huang, D.; Zhang, C.; Qin, L.; Hu, L.; Zhou, C.; Xiong, W.; Coord. Chem. Rev. 2018, 368,80 .

59. Cai, C.; Zhang, Z.; Liu, J.; Shan, N.; Zhang, H.; Dionysiou, D. D.; Appl. Catal., B 2016, 182, 456.

Submitted: January 31, 2019 Published online: May 21, 2019 